\title{
Oxidative stress and antioxidant indices of the marine red alga Porphyra vietnamensis
}

\author{
NAVNATH M. Pise ${ }^{1, *}$, DATTATRy K. GaikWAD ${ }^{2}$, TANAJi G. JAGTAP ${ }^{1}$ \\ ${ }^{1}$ Biological Oceanography Division, National Institute of Oceanography, \\ Council of Scientific and Industrial Research, Dona Paula, Goa 403004, India \\ 2 Botany Department, Shivaji University, Kolhapur, Maharashtra 416004, India
}

\begin{abstract}
Oxidative stress and antioxidant defence systems were assessed in a marine red alga Porphyra vietnamensis Tanaka et Pham-Hoang Ho, from India. Lipid peroxidation (LPX) and hydrogen peroxide $\left(\mathrm{H}_{2} \mathrm{O}_{2}\right)$ were measured as oxidative stress markers. Antioxidant defences were measured as catalase (CAT), glutathione $S$-transferase (GST) and ascorbic acid (AsA), in order to understand their dissimilarity with respect to environmental conditions (pollution levels) from selective locations along the central west coast of India. Levels of LPX, $\mathrm{H}_{2} \mathrm{O}_{2}$, CAT and GST were significantly higher in samples collected from Dona Paula than in samples from Malvan and Kunkeshwar, while a lower concentration of AsA was found in samples from Dona Paula. Heavy metals such as $\mathrm{Cd}, \mathrm{Pb}$ and $\mathrm{Hg}$ in higher concentrations in these areas than in other sites were also observed. Variation of oxidative stress indices in response to the accumulation of heavy metals within $P$. vietnamensis could be used as molecular biomarkers for the assessment and monitoring of environmental quality in ecologically sensitive marine habitats.
\end{abstract}

Key words: Porphyra vietnamensis, lipid peroxidation, antioxidant, biomarker, oxidative stress

\section{Introduction}

Natural antioxidants are found in some vegetables, fruits and a variety of other foods (Moon and Shiвамото 2009). Many researchers reported the occurrence of various antioxidants in seaweeds, including polysaccharides, dietary fibers, minerals, proteins, amino acids, vitamins, polyphenols and carotenoids (BURTIN 2003). Seaweeds produce antioxidants to counteract environmental stresses (LESSER 2006). In the intertidal zones of rocky beaches around the world, marine algae are exposed to constantly fluctuating and extreme abiotic conditions in, for example, temperature, salinity, $\mathrm{pH}$, and heavy metal pollution,

\footnotetext{
* Corresponding author, e-mail: pisenavnath@gmail.com

Copyright $^{\circledR} 2013$ by Acta Botanica Croatica, the Faculty of Science, University of Zagreb. All rights reserved.
} 
resulting in intermittent intracellular oxidative stress conditions developed by the accumulation of reactive oxygen species (ROS) (DAVISON and PEARSON 1996, MitTLER 2002, PINTO et al. 2003). In biological systems, reactive oxygen species (ROS) such as singlet oxygen $\left({ }^{1} \mathrm{O}_{2}\right)$, hydrogen peroxide $\left(\mathrm{H}_{2} \mathrm{O}_{2}\right)$, superoxide anion radical $\left(\mathrm{O}_{2}^{-}\right)$and hydroxyl radical $\left(\mathrm{OH}^{-}\right)$are produced in normal metabolic pathways, as well as from exposure of different xenobiotic substances (HALLIWELL and GUTTERIDGE 2001). Reactive oxygen species are produced directly by excitation of $\mathrm{O}_{2}$ and subsequent formation of singlet oxygen, or by the transfer of electrons to $\mathrm{O}_{2}$, which results in the formation of superoxide radicals, hydrogen peroxide $\left(\mathrm{H}_{2} \mathrm{O}_{2}\right)$, or hydroxyl radicals, respectively (BAKER and ORLANDI 1995).

Marine algae are a fundamental part of marine food webs, since they are responsible for most of coastal primary production (LOBBAN and HARRISON 1994). Adverse effects on macroalgae caused by natural or anthropogenic phenomena can directly or indirectly affect organisms at higher trophic levels and, finally, the integrity of entire ecosystems (MEDINA et al. 2005). Marine algae protect themselves against such reactive oxygen, to some extent by developing anti-oxidant defence systems, which constitute both enzymatic and non-enzymatic biomolecules, such as superoxide dismutase (SOD), catalase (CAT), glutathione peroxidase (GPX), glutathione $S$-transferase (GST), reduced glutathione (GSH), and ascorbic acid (AsA) (HALliwell and GuTTERIDGe 2001).

Marine algae or seaweeds have been found to be notable bioindicator species in environmental pollution studies (SAWIDIS et al. 2001, CONTI and CECCHETTI 2003, MOACIR et al. 2008). Brown algae, for instance, accumulate considerable quantities metals due to the presence of negatively charged polysaccharides (SALGADO et al. 2005). The aim of this study was to examine the various oxidative stress and antioxidant indices in Porphyra vietnamensis, from the central west coast of India, Arabian Sea. This is the first known study applying oxidative stress indices to $P$. vietnamensis, a potential model for evaluating marine environmental health.

\section{Materials and methods}

\section{Site description}

Algal samples (P. vietnamensis) were collected from the central west coast of India (Fig. 1). Two sites were selected from the coast of Maharashtra: Malvan $\left(16^{\circ} 03^{\prime} 47.5^{\prime \prime} \mathrm{N}\right.$, $\left.73^{\circ} 27^{\prime} 22.5^{\prime \prime} \mathrm{E}\right)$ and Kunkeshwar (16 20'02.4” N, $\left.73^{\circ} 31.3^{\prime \prime} \mathrm{E}\right)$, which is a cliff-locked beach. From Goa, one site was selected: Dona Paula $\left(15^{\circ} 51^{\prime} \mathrm{N}, 73^{\circ} 53^{\prime} \mathrm{E}\right)$ which receives various effluents from the Zuari estuary.

\section{Sample collection}

The red alga $P$. vietnamensis (Family Bangiaceae) is common in the intertidal zone of India. Fresh fronds of $P$. vietnamensis were collected from the intertidal zones at the three sites during low tides in April 2011. Whole fronds with holdfast were handpicked, washed in seawater and then in ice cold distilled water, and immediately frozen in liquid nitrogen. 


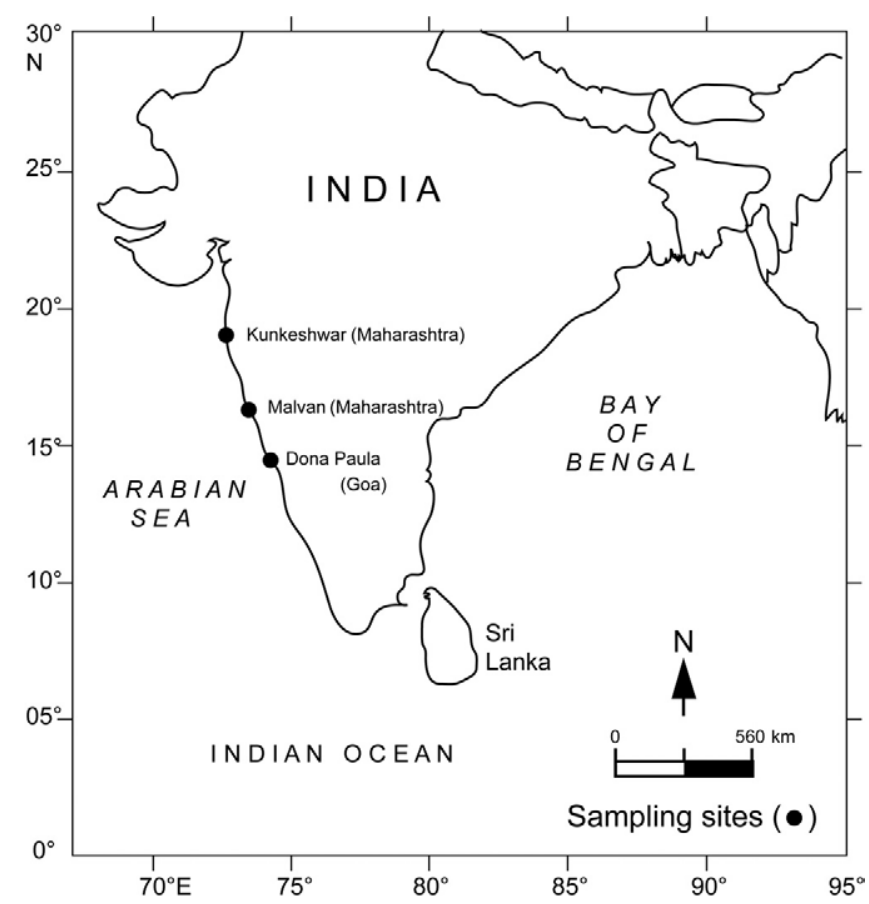

Fig. 1. Sampling sites for Porphyra vietnamensis collected from the central west coast of India, Arabian Sea.

\section{Physico-chemical parameters}

Physico-chemical parameters at each site were measured during the study period (Tab. 1). Surface water salinity was measured with a portable Salinity Refractometer (ATAGO, $\mathrm{S} / \mathrm{Mill}$, Japan). The $\mathrm{pH}$ of the surface water was measured by a scan microprocessor-based pocket $\mathrm{pH}$ tester (YK-35425-10, OAKTON, Malaysia). Surface water temperature was noted using a mercury thermometer at the time of collection.

Tab. 1. Physico-chemical parameters of water bodies in different locations during sampling periods

\begin{tabular}{cccr}
\hline Parameter & Malvan & Kunkeshwar & Dona Paula \\
\hline Water Temp. $\left({ }^{\circ} \mathrm{C}\right)$ & $27.5 \pm 0.86$ & $26.3 \pm 2.20$ & $25.36 \pm 0.60$ \\
pH & $8.06 \pm 0.67$ & $7.96 \pm 0.73$ & $8.10 \pm 0.37$ \\
Salinity (PSU) & $20.6 \pm 1.50$ & $25.3 \pm 3.21$ & $22.3 \pm 4.93$ \\
\hline
\end{tabular}

\section{Metal analysis}

Metal contents were analyzed by digesting $0.5 \mathrm{~g}$ of dry algal powder in $20 \mathrm{~mL}$ of concentrated $\mathrm{HNO}_{3}$ in a beaker covered with a watch glass. After complete digestion, the samples were diluted to $100 \mathrm{ml}$ and filtered through Whatman No.1 filter paper (Merck, Mumbai, India). The acid digest was analyzed for heavy metals such as cadmium (Cd), lead 
Pise N. M., Gaikwad D. K., JagtaP T. G.

$(\mathrm{Pb})$ and mercury $(\mathrm{Hg})$ using atomic absorption spectrophotometry (Analyst 300 Perkin-Elmer, Waltham, MA, USA; AOAC 2005).

\section{Oxidative stress indices}

\section{Lipid peroxidation}

Lipid peroxidation (LPX) was measured according to the malondialdehyde (MDA) content, a product of LPX estimated by the thiobarbituric acid (TBA) reaction (HEATH and PACKER 1968). A fresh algal sample $(0.5 \mathrm{~g})$ was homogenized in $5 \mathrm{~mL}$ of $10 \%$ (W/V) trichloro acetic acid (TCA), and the homogenate was centrifuged at $7000 \times g$ for $10 \mathrm{~min}$. One $\mathrm{ml}$ of the supernatant was mixed with $2 \mathrm{~mL}$ of $0.5 \%$ TBA solution (in $10 \%$ TCA). Then the mixture was heated at $95^{\circ} \mathrm{C}$ for $45 \mathrm{~min}$ and then cooled at room temperature. The supernatant was read at $532 \mathrm{~nm}$ after the removal of interfering substances by centrifuging at $4000 \mathrm{x} \mathrm{g}$ for $10 \mathrm{~min}$. The amount of thiobarbituric acid reactive substances (TBARS) formed was calculated by using an extinction coefficient of $1.56 \times 10^{5} \mathrm{M}^{-1} \mathrm{~cm}^{-1}$ (WILLS 1969), and expressed as nmol TBARS per $g$ of wet tissue.

\section{Hydrogen peroxide content}

The $\mathrm{H}_{2} \mathrm{O}_{2}$ content was determined according to SERGIEV et al. (1997). Algal material (0.5 g) was homogenized with $5 \mathrm{~mL}$ of $10 \%(\mathrm{~W} / \mathrm{V})$ TCA in an ice bath. The homogenate was centrifuged at $7000 \times g$ for $10 \mathrm{~min}$, and the supernatant $(0.5 \mathrm{~mL})$ was added with $1.5 \mathrm{~mL}$ of $50 \mathrm{mM}$ potassium phosphate buffer $(\mathrm{pH} 7.0)$ and $1 \mathrm{~mL}$ of $1 \mathrm{M}$ potassium iodide (KI), and the absorbance was measured at $390 \mathrm{~nm}$ (UV 1800, Shimadzu, Japan). $\mathrm{H}_{2} \mathrm{O}_{2}$ was used as a standard and expressed as nmol $\mathrm{H}_{2} \mathrm{O}_{2}$ per $\mathrm{g}$ of wet tissue.

\section{Preparation of enzyme extracts}

Frozen algal samples $(0.5 \mathrm{~g})$ were homogenized in ice cold $50 \mathrm{mM}$ potassium phosphate buffer (pH 7.0) containing $0.1 \%(\mathrm{~V} / \mathrm{V})$ Triton $\mathrm{X}-100$ and $1 \%(\mathrm{~W} / \mathrm{V})$ polyvinylpyrollidone (PVP). The homogenate was centrifuged at $10,000 \times \mathrm{g}$ for $15 \mathrm{~min}$ at $4{ }^{\circ} \mathrm{C}$, and the supernatants were used for enzyme assays.

\section{Catalase}

The activity of CAT was measured by slightly modifying the method of AEBI (1974). The assay mixture contained $2.9 \mathrm{~mL}$ of $15 \mathrm{mM} \mathrm{H}_{2} \mathrm{O}_{2}$ in $50 \mathrm{mM}$ potassium phosphate buffer ( $\mathrm{pH} 7.0$ ) and $0.1 \mathrm{~mL}$ of enzyme extract. The decomposition of $\mathrm{H}_{2} \mathrm{O}_{2}$ was followed by a decline in absorbance at $240 \mathrm{~nm}$. The enzyme activity was expressed as nkat per mg of protein $\left(1 \mathrm{katal}=1 \mathrm{~mol} \mathrm{sec}^{-1}\right)$.

\section{Glutathione $S$-transferase}

GST activity was measured by using 1-chloro-2, 4-dinitrobenzene (CDNB) as a substrate, according to the protocol by HABIG et al. (1974). The reaction rate was recorded at $340 \mathrm{~nm}$, and enzyme activity was expressed as nmol CDNB conjugate formed/(min.mg protein), using a molar extinction coefficient of $9.6 \mathrm{mM}^{-1} \mathrm{~cm}^{-1}$. Protein content was estimated by the Folin-Phenol reaction as described by LowRY et al. (1951). 


\section{Ascorbic acid content}

Algal material was homogenized in an ice bath with $5 \mathrm{~mL}$ of $10 \%$ (W/V) TCA and centrifuged at $7000 \times g$ for 10 minutes. The deproteinised supernatant was used as assay for ascorbic acid following the stoichiometric reduction of phosphomolybdate by ascorbic acid (Mitusi and OHATA 1961). AsA was used as the standard, and results were expressed as $\mu \mathrm{g}$ AsA per $g$ of wet tissue.

\section{Statistical analysis}

Microsoft excel (Excel-2007) was used for statistical analyses. ANOVA analysis was used to compare sampling stations and a Tukey test was applied for post-hoc comparisons (ZAR 1996). Differences between means $(n=5)$ were considered significant when $\mathrm{p}<0.05$. Pearson correlation analyses $(\mathrm{p}<0.05)$ were tested between metal levels in Porphyra vietnamensis and oxidative stress responses.

\section{Results}

\section{Physico-chemical parameter}

During the present study, water temperature varied from 25.36 to $27.5^{\circ} \mathrm{C}$; the minimum temperature $\left(25.36{ }^{\circ} \mathrm{C}\right)$ of water was recorded at Dona Paula, and the maximum $\left(27.5^{\circ} \mathrm{C}\right)$ at Malvan. The overall differences in temperatures are consistent with normal variations. The $\mathrm{pH}$ varied from 7.96 to 8.10 indicating normal variation. The minimum $\mathrm{pH}$ value (7.96) was recorded at Kunkeshwar and maximum (8.10) at Dona Paula during the sampling period (Tab. 1). The salinity of water ranged from 22.3 to 25.3. Kunkeshwar showed the maximum salinity (25.3) and minimum at Malvan (20.6), during the monsoon sampling period.

\section{Metal analysis}

In the present study heavy metal contents in Porphyra vietnamensis from Kunkeshwar, Malvan and Dona Paula ranged from 0.47 to $1.98 \mu \mathrm{g} \mathrm{g}^{-1}$ dry weight and occurred in the following rank order of abundance: $\mathrm{Hg}<\mathrm{Cd}<\mathrm{Pb}$ ( Tab. 2). The comparatively higher values of these metals from samples of Dona Paula and Malvan could be attributed to higher levels than the Kunkeshwar. Maximum concentrations of metals in P. vietnamensis, from Dona Paula during the monsoon study period, could be due to the disturbances to the substratum, resulting from intensive river runoff and strong currents.

Tab. 2. Metal accumulation ( $\mathrm{mg} \mathrm{g}^{-1}$ dry weight) in tissues of Porphyra vieatnamensis at different sampling sites

\begin{tabular}{cccc}
\hline Metal & Malvan & Kunkeshwar & Dona Paula \\
\hline $\mathrm{Pb}\left(\mu \mathrm{g} \mathrm{g}^{-1}\right)$ & $1.77 \pm 0.09$ & $1.22 \pm 0.09$ & $1.98 \pm 0.17$ \\
$\mathrm{Cd}\left(\mu \mathrm{g} \mathrm{g}^{-1}\right)$ & $0.68 \pm 0.06$ & $0.67 \pm 0.15$ & $0.98 \pm 0.18$ \\
$\mathrm{Hg}\left(\mu \mathrm{g} \mathrm{g}^{-1}\right)$ & $0.58 \pm 0.09$ & $0.47 \pm 0.015$ & $0.99 \pm 0.19$ \\
\hline
\end{tabular}




\section{Lipid peroxidation}

In the present study, LPX values were significantly higher in the samples from Dona Paula and Malvan than in the samples from Kunkeshwar (Fig. 2A, p < 0.05). Similarly, enhanced levels of $\mathrm{H}_{2} \mathrm{O}_{2}$ were also noticed in the samples from Dona Paula (Fig. 2B). Increased levels of LPX and $\mathrm{H}_{2} \mathrm{O}_{2}$ in P. vietnamensis from different localities were significantly correlated with the heavy metal concentrations (Tab. 2, p < 0.001).

(A) LPX
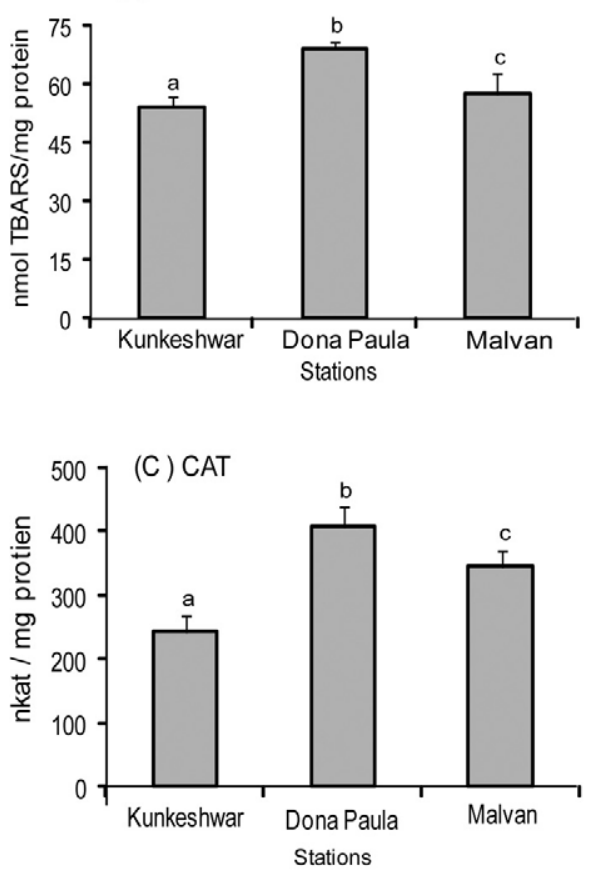
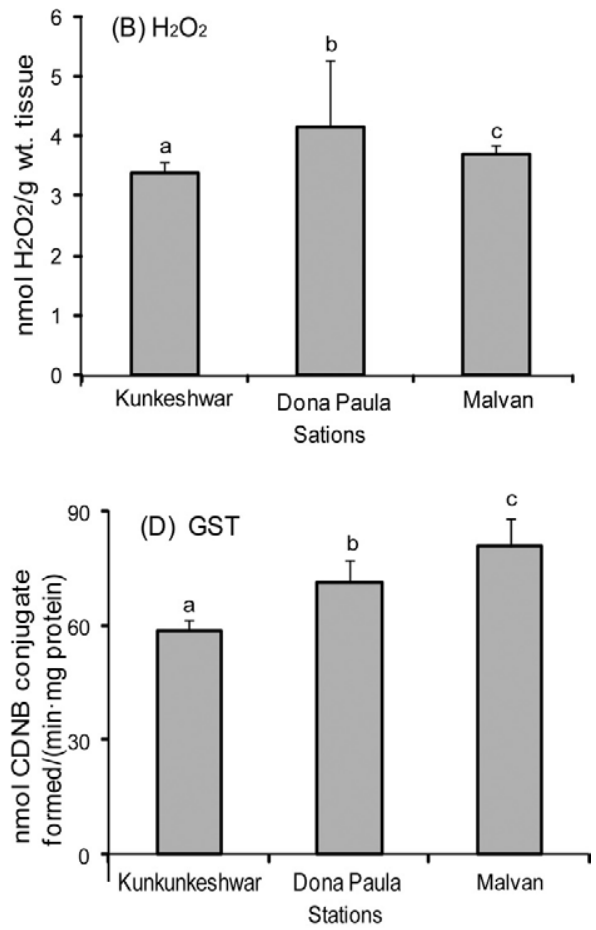

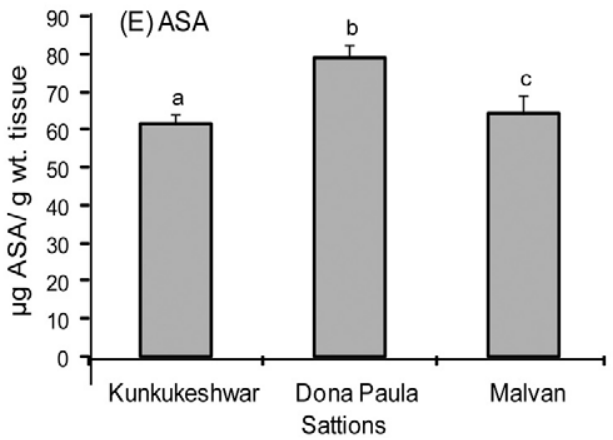

Fig. 2. Biochemical measurements at different sites along the central west coast of India. A - Lipid peroxidation (LPX), B - hydrogen peroxide $\left(\mathrm{H}_{2} \mathrm{O}_{2}\right), \mathrm{C}$ - catalase (CAT), D - glutathion $S$-transferase (GST), E - ascorbic acid content (AsA). The alphabetical letters (a, b, c) mark significant difference at $\mathrm{p}<0.05$. 


\section{Antioxidant defence systems}

In the present study, CAT activity was significantly higher in the sample from Dona Paula and Malvan, further indicating metal stress increasing the formation rate of $\mathrm{H}_{2} \mathrm{O}_{2}$ (Fig. 2B). Interestingly higher levels of $\mathrm{H}_{2} \mathrm{O}_{2}$ were measured in samples from Dona Paula than those from other sites (Fig. 2B). The induction of CAT activity in P. vietnamensis from Dona Paula could be attributed to the unfavorable environmental conditions. Also observed were increased levels of GST activity in P. vietnamensis samples from Malvan and Dona Paula, compared to those from Kunkeshwar (Fig. 2D). High concentrations of AsA were also recorded in the samples from Dona Paula and Malvan as compared to Kunkehwar (Fig. 2E) which suggest that AsA synthesis might have been stimulated to protect against a metal-contaminated environment. This response appeared to be particularly associated with physico- chemical parameters $(\mathrm{Pb}, \mathrm{Cd}, \mathrm{Hg}$, temperature, $\mathrm{pH}$ and salinity) and also a significant correlation was found ( $<<0.001$, Tab. 3$)$.

Tab. 3. Correlation coefficients (r) between physico-chemical and biochemical parameters

\begin{tabular}{|c|c|c|c|c|c|}
\hline \multirow{2}{*}{$\begin{array}{l}\text { Phy.-chem. } \\
\text { Parameter }\end{array}$} & \multicolumn{5}{|c|}{ Biochemical Parameters } \\
\hline & CAT & ASA & GST & LPX & $\mathrm{H}_{2} \mathrm{O}_{2}$ \\
\hline $\mathrm{Pb}$ & $\mathrm{r}=0.99 * * *$ & $\mathrm{r}=0.82 * * *$ & $\mathrm{r}=0.76 * *$ & $\mathrm{r}=0.84 * * *$ & $\mathrm{r}=0.94 * * *$ \\
\hline $\mathrm{Cd}$ & $\mathrm{r}=0.77 * *$ & $\mathrm{r}=0.98 * * *$ & $\mathrm{r}=0.06$ & $\mathrm{r}=0.97 * * *$ & $\mathrm{r}=0.89 * * *$ \\
\hline $\mathrm{Hg}$ & $\mathrm{r}=0.65^{*}$ & $\mathrm{r}=0.93 * * *$ & $\mathrm{r}=-0.11$ & $\mathrm{r}=0.91 * * *$ & $\mathrm{r}=0.80 * *$ \\
\hline Water Temp. $\left({ }^{\circ} \mathrm{C}\right)$ & $\mathrm{r}=0.45$ & $\mathrm{r}=0.81 * * *$ & $r=-0.35$ & $\mathrm{r}=0.78 * *$ & $\mathrm{r}=0.63 *$ \\
\hline $\mathrm{pH}$ & $\mathrm{r}=0.99 * * *$ & $\mathrm{r}=0.84 * * *$ & $\mathrm{r}=0.73 *$ & $\mathrm{r}=0.86 * * *$ & $\mathrm{r}=0.95 * * *$ \\
\hline Salinity (PSU) & $\mathrm{r}=-0.99 * * *$ & $\mathrm{r}=-0.87 * * *$ & $\mathrm{r}=-0.64 *$ & $\mathrm{r}=-0.89 * * *$ & $\mathrm{r}=-0.96 * * *$ \\
\hline
\end{tabular}

Significance level: $\mathrm{P}<0.05(*), \mathrm{P}<0.01(* *), \mathrm{P}<0.001(* * *)$

\section{Discussion}

This study represents the most extensive work on oxidative stress induced by temperature, salinity, $\mathrm{pH}$ and metal concentration from selected sites along central west coast of India. Heavy metals are implicated in oxidative injury involved in the formation of ROS and their subsequent attack on proteins, lipids, and nucleic acids, leading to loss of enzyme functions, altered membrane fluidity, and genomic damage (DIETZ et al. 1999).

The physical, chemical and biological features of the coastline and estuarine systems of Goa are adapted to a seasonal rhythm, the monsoon cycle. Increased precipitation and land runoff during the monsoon season causes dynamic changes from typically marine to brackish water conditions (QASIM and SEN GUPTA 1981) resulting in changes in temperature, salinity, $\mathrm{pH}$ and metal levels along outer coasts and in estuaries. The water in the Goan estuaries remains well mixed during the pre-monsoon season and gets stratified during the monsoon (QASIM and SEN GUPTA 1981), while diurnal variations in physico-chemical conditions are governed by the tides (SingBal 1976). The high precipitation and freshwater influx brings cooler water from the upper reaches of the river, resulting in lower water temperatures during monsoons. It also results in higher $\mathrm{pH}$ values due to dilution of 
seawater by fresh water inflow (DEHADRAI and BHARGAVA 1972). Solar radiation during the monsoon is reduced because of heavy cloud cover that decreases temperature and the rate of evaporation, thus maintaining lower salinity. However, decreased salinity can be attributed predominantly to heavy precipitation and the influx of fresh water (DEHADRAI and BHARGAVA 1972).

\section{Metal analysis}

The concentration of heavy metals, in marine environments is mainly influenced by both natural and anthropogenic sources. In coastal waters, metals can occur at much higher concentrations, probably due to inputs from river systems (MoRILLO et al. 2004). However, other metals, such as $\mathrm{Cd}, \mathrm{Hg}$, and $\mathrm{Pb}$, are toxic even at very low concentrations (WoOD 1974, NIES 1999). Marine algae are known to concentrate metals, and it is the increased concentration especially of non-essential trace metals such as $\mathrm{Cd}, \mathrm{Pb}, \mathrm{Hg}$ that could induce oxidative stress in their tissues (KUMAR et al. 2010). It has been reported that these polluted areas (along the Goa coastline) receive varieties of pollutants including metals, petrochemicals as well as sewage generated from various anthropogenic activities (CPCB 1996).

\section{Lipid peroxidation}

Metal levels in tissue induce a variety of cellular changes, such as damage to membrane integrity (SMEETS et al. 2005), reduction in photosynthesis and impairment of $\mathrm{CO}_{2}$ assimilation (VAN ASSCHE and CLIJSTERS 1990, Gouia et al. 2003), which may produce ROS and resulting LPX. Similar results were reported in brown seaweed Padina tetrastromatica at polluted locations in Karwar and Colaba (MAHARANA et al. 2010). This suggests that changes in oxidative stress and antioxidant levels might be to the contaminant metals or abiotic factors such as cadmium, mercury, lead, temperature, salinity and $\mathrm{pH}$. Induction of LPX levels were also reported in plants exposed to Cd (LiU et al. 2007) and Pb (REDDY et al. 2005, DAZY et al. 2009).

\section{Antioxidant defence systems}

Ozone, salt stress, drought, heat, heavy metals, toxins and organic pollutants also induce the formation of reactive oxygen (PFLUGMACHER 2004). In addition, photosynthetic organisms continuously produce reactive oxygen during photosynthesis and other metabolic processes (FOYER and NOCTOR 2000). The defence system against reactive oxygen in plants includes antioxidants such as ascorbate, glutathione, $\beta$ - carotene and a- tocopherol and reactive oxygen scavenging enzymes, such as catalase (EC 1.11.1.6), superoxide dismutase (SOD, EC 1.15.1.1), glutathione reductase (GR, EC 1.6.4.2) and ascorbate peroxidase (APX, EC 1.11.1.11). Higher levels of antioxidants, and increased activities of reactive oxygen scavenging enzymes, correlate with stress tolerance in seaweeds, e.g. brown algae of the genus Fucus (COLLEN and DAVISON 1999 a, b).

Catalase is a porphyrin-containing enzyme which catalyses the decomposition of hydrogen peroxide to water and oxygen (ARUOMA 1998). A significant correlation was observed between CAT and $\mathrm{H}_{2} \mathrm{O}_{2}$ scavenging action $(\mathrm{r}=0.97, \mathrm{p}<0.001)$. This suggests either that catalase is the most important enzyme for the breakdown of $\mathrm{H}_{2} \mathrm{O}_{2}$. Increased CAT activity has been described in several aquatic species from impacted areas both by metals 
and organic contaminants (ORBEA et al. 2002, NIMPTSCH et al. 2005). Catalase activity increased with treatements with $\mathrm{Cd}$ and $\mathrm{Pb}$ (DAZY et al. 2009). ColLEN et al. (2003) also reported that the heavy metals also induced the activity of catalase in the G. tenuistipitata. Nevertheless, CAT induction in plants has only been reported under laboratory conditions (Roy et al. 1995, RAMA Devi and PRASAd 1998, Collén et al. 2003).

GST is also capable of detoxifying ROS and its activity increases in cases of oxidative stress in plant cells (PflugmaCHER et al. 1999, Thом et al. 2001). The observed increase in GST activity at Dona Paula site (Tab. 3), and the positive correlation with $\mathrm{Pb}(\mathrm{p}<0.01$;) and $\mathrm{pH}(\mathrm{p}<0.05)$ suggest that higher metal stress might have induced GST levels to combat tissues from xenobiotic substances. Similar findings were observed in Padina terastromastica (MAHARANA et al 2010). GST activity has also been observed in plants treated with Cd (ArAvind and Prasad 2005, Mishra et al. 2009).

Although few studies have reported on AsA levels in response to polluted environmental conditions, interestingly, a significant increase in AsA content was observed in response to Cd (MAHARANA et al. 2010, Aravind and Prasad 2005). A significant correlation between AsA and $\mathrm{Cd}(\mathrm{r}=0.98, \mathrm{p}<0.001)$ levels in the algal tissue also supports this statement (Tab. 3). AsA and GSH are direct scavengers of ROS, and an additional substrate for various antioxidant enzymes (HALLIWELL and GUTTERIDGE 1999). It has been reported that theascorbateglutathione cycle (AGC) plays an important role in detoxification of ROS (KUZNIAK and MARIA 2001). Important activities of CAT, GST and ASA consequent to increased LPX and $\mathrm{H}_{2} \mathrm{O}_{2}$ suggest that $P$. vietnamensis maintains sufficient antioxidant defences to withstand major environmental turbulence related to different stations and abiotic parameters. The evaluation of abiotic parameters and metal concentrations in $P$. vietnamensis appears to confirm such a relationship (Tab. 3).

\section{Conclusions}

Porphyra vietnamensis displays different biochemical responses to environmental conditions. Elevated levels of LPX and $\mathrm{H}_{2} \mathrm{O}_{2}$, indicate a state of oxidative stress possibly due to accumulation of metal ions. The present data revealed that oxidative stress markers such as LPX and $\mathrm{H}_{2} \mathrm{O}_{2}$, and nonenzymatic antioxidant such as AsA and antioxidant enzymes (CAT and GST) may be useful biomarkers, suggesting that this species might be a model species for the evaluation and monitoring of marine environments.

\section{Acknowledgments}

The authors are thankful to the Director, National Institute of Oceanography, Goa for the facilities and encouragement. This work was carried under the funds from contingency funds from the CSIR -SRF (RF-82609) fellowship.

\section{References}

Aebi, H., 1974: Catalase. In: Bergmeyer, H. U. (ed.), Methods in enzymatic analysis, 2, 673-678. Academic Press, New York. 
Aravind, P., Prasad, M. N. V., 2005: Modulation of cadmium-induced oxidative stress in Ceratophyllum demersum by zinc involves ascorbate-glutathione cycle and glutathione metabolism. Plant Physiology and Biochemistry 43, 107-116.

ARUOMA, I. O., 1998: Free radicals, oxidative stress and antioxidants in human health and disease. Journal of American Oil Chemists Society 75, 199 - 221.

BAKer, C. J., Orlandi, E. W., 1995: Active oxygen in plant pathogenesis. Annual Review of Phytopathology 33, 299-321.

BurTin, P., 2003: Nutritional value of seaweeds. Electronic Journal of Environmental Agricultural and Food Chemistry 2, 498-503.

Conti, M. E., CECChetTi, G. A., 2003: Biomonitoring study: trace metals in algae and molluscs from Tyrrhenian coastal areas. Environmental Research 93, 99-112.

Collen, J., Davison I. R., 1999a: Stress tolerance and reactive oxygen metabolism in the intertidal seaweeds Mastocarpus stellatus and Chondrus crispus. Plant Cell and Environment 22, 1143 - 1151 .

Collen, J., Davison, I. R., 1999b: reactive oxygen production and damage in intertidal Fucus spp. (Phaeophyceae). Journal of Phycology 35, 54-61.

Collen, J., Pinto, E., Pedersen, M., Colepicolo, P., 2003: Induction of oxidative stress in the red macroalgae Gracillaria tenuistipitata by pollutant metals. Archives of Environmental Contamination and Toxicology 45, 337-342.

CPCB (Central Pollution Control Board), 1996: Coastal pollution. Technical publication Government of India, New Delhi, 30.

Davison, I. R., Pearson, G. A. 1996: Environmental stress in intertidal seaweeds. Journal of Phycology 32, 197-211.

DAZY, M., MAsFaraud, J. F., FerARD, J. F., 2009: Induction of oxidative stress biomarkers associated with heavy metal stress in Fontinalis antipyretica Hedw. Chemosphere 75, 297-302.

Dietz, K. J., BAiER, M., KrAmer, U., 1999: Free radicals and reactive oxygen species as mediators of heavy metal toxicity in plants. In: Prasad, M. N. V., Hagemeyer, J. (eds.), Heavy metal stress in plants - from molecules to ecosystems, 73-97. Springer-Verlag, Berlin.

DeHADRAI, P. V., BhaRgaVA, R. M. S. 1972: Seasonal organic production in relation to environmental features in Mandovi and Zuari estuaries, Goa. Indian Journal of Marine Sciences 1, 52-56.

Foyer, C. H., Noctor, G., 2000: Oxygen processing in photosynthesis: Regulation and signaling. New Phytologist 146, 359-388.

Gouia, H., Suzuki, A., Brulfert, J., Ghorbal, M. H., 2003: Effects of cadmium on the co-ordination of nitrogen and carbon metabolism in bean seedlings. Journal of Plant Physiology 160, 367-376.

HABIG, W. H., PABST, M. J., JAKOBY, W. B., 1974: Glutathione $S$-transferases: The first enzymatic step in mercapturic acid formation. Journal of Biological Chemistry 249, 71307139. 
Halliwell, B., GutTeridge, J. M. C., 1999: Oxydative stress. In: Halliwell, B., GutTeRIDGE, J. M. C. (eds.), Free radicals in biology and medicine, 2, 246-350. Oxford University Press, New York.

Halliwell, B., Gutteridge, J. M. C., 2001: Reactive species can be poisonous. In: HalliWell, B., GutTeridge, J. M. C. (eds.), Free radicals in biology and medicine, 4, 440487. Oxford University Press, New York.

Heath, R. L., Packer, L., 1968: Photoperoxidation in isolated chloroplasts I. Kinetics and stoichiometry of fatty acid peroxidation. Archives of Biochemistry and Biophysics 125, 189-198.

Kumar, S. V., Saritha, G., Fareedullah, M. D., 2010: Role of antioxidants and oxidative stress in cardiovascular disease. Annals of Biological Research 1, 158-173.

KuZNIAK, E., MARIA, S., 2001: Ascorbate, glutathione and related enzymes in chloroplasts of tomato leaves infected by Botrytis cinerea. Plant Science 160, 723-731.

LeE, M. Y., Shin, H. W., 2003: Cadmium-induced changes in antioxidant enzymes from the marine alga Nannochloropsis oculata. Journal of Applied Phycology 15, 13-19.

LESSER, P. M., 2006: Oxidative stress in marine environments: biochemistry and physiological ecology. Annual Review Physiology 68, 253-278

Liu, Y., Wang, X., Zeng, G., Qu, D., Gu, J., Zhou, M., ChaI, L., 2007: Cadmium-induced oxidative stress and response of the ascorbate-glutathione cycle in Bechmeria nivea (L) Gaud. Chemosphere 69, 99-107.

Lobban, C. S., Harrison, P. J., 1994: Seaweed ecology and physiology. Cambridge University Press, New York.

Lowry, O. H., Rosebrough, N. J., FArR, A. L., Randall, R. J., 1951: Protein measurement with the Folin phenol reagent. Journal of Biological Chemistry 193, 265-275.

Maharana, D., Jena, K. B., Pise, N. M., Jagtap, T. G., 2010: Assessment of oxidative stress indices in a marine macro brown alga Padina tetrastromatica (Hauck) from comparable polluted coastal regions of the Arabian Sea, west coast of India. Journal of Environmental Sciences 22, 1413-1418.

Medina, M., Andrade, S., Faugeron, S., Lagos, N., Mella, D., Correa, J. A., 2005: Biodiversity of rocky intertidal benthic communities associated with copper mine tailing discharges in northern Chile. Marine Pollution Bulletin 50, 396-409.

Mishra, S., Tripathi, R. D., Srivastava, S., Dwivedi, S., Trivedi, P. K., Dhankher, O. P., KHARE, A., 2009: Thiol metabolism play significant role during cadmium detoxification by Ceratophyllum demersum L. Bioresource Technology 100, 2155-2161.

MitTleR, R. 2002: Oxidative stress, antioxidants and stress tolerance. Trends in Plant Science 7, 405-410.

Mitusi, A., OHATA, T., 1961: Photooxidative consumption and photoreductive formation of ascorbic acid in green leaves. Plant Cell Physiology 2, 31-44.

Moacir, A., Torres, M., Barros, P., Sara, C. G., Campos-Ernani, P., Satish, R., RichARD, T. S., PIO, C., 2008: Ã Biochemical biomarkers in algae and marine pollution: A review. Ecotoxicology and Environmental Safety 71, 1- 15.

Moon, J., Sнiвамото, T., 2009: Antioxidant assays for plant and food components. Journal of Agricultural Food Chemistry 57, 1655-1666. 
Morillo, J., Usero, G., Gracia, I., 2004: Heavy metal distribution in marine sediments from the southwest of Spain. Chemosphere 55, 431-442.

NIES, D. H., 1999: Microbial heavy metal resistance. Applied Microbiology and Biotechnology 51, 730-750.

Nimptsch, J., Wunderlin, D. A., Dollan, A., Pflugmacher, S., 2005: Antioxidant and biotransformation enzymes in Myriophyllum quitense as biomarkers of heavy metal exposure and eutrophication in Suquia River basin (Codoba, Argentina), Chemosphere 261, 147-157.

Orbea, A., Ortiz-Zarragoitia, M., Sole, M., Porte, C., Cajaraville, M., 2002: Antioxidant enzymes and peroxisome proliferation in relation contaminant body burdens of PAHs and PCBs in bivalvia molluscs, crabs and fish from Urdiabai and Plentzia estuaries (Bay of Biscay). Aquatic Toxicology 58, 75-98.

PflugmaCher, S., 2004: Promotion of oxidative stress in the aquatic macrophyte Ceratophyllum demersum during biotransformation of the cyanobacterial toxin microcystin-LR. Aquatic Toxicology 70, 169-178.

Pflugmacher, S., Wiencke, C., Sandermann, H., 1999: Activity of phase I and phase II detoxication enzymes in Antarctic and Arctic macroalgae. Marine Environmental Research 48, 23-36.

Pinto, E., Sigaud-Kutner, T. C. S., Leitao, M. A., Okamoto, O. K., Morse, D., ColePICOLO, P., 2003: Heavy metal-induced oxidative stress in algae. Journal of Phycology 39, 1008-1018.

QASIM, S. Z., SEN GuPTA, R., 1981: Environmental characteristics of the Mandovi - Zuari Estuarine system in Goa. Estuarine Coastal and Shelf Science 13, 557-578.

Rama-Devi, S., Prasad, M. N. V., 1998: Copper toxicity in Ceratophyllum demersum L. (Coontail), a free floating macrophyte: response of antioxidant enzymes and antioxidants. Plant Science 138, 157-165.

Reddy, A. M., Kumar, S. G., Jyothsnakumari, G., Thimmanaik, S., Sudhakar, C., 2005 : Lead induced changes in antioxidant metabolism of horsegram (Macrotyloma uniflorum Lam. Verdc.) and bengalgram (Cicer arietinum L.). Chemosphere 60, 97-104.

Roy, S., Lindstom-Seppa, P., HuUskonen, S., Hanninen, O., 1995: Responses of biotransformation and antioxidant enzymes in Lemna minor and Oncorhynchus mykiss exposed simultaneously to hexachlorobenzene. Chemosphere 30, 1489-1498.

Salgado, L. T., Andrade, L. R., Amado-Filho, G. M., 2005: Localization of specific monosaccharide in cells of the brown alga Padina gymnospora and the relation to heavy-metal accumulation. Protoplasma 225, 132-128.

SAwidis, T., Brown, M. T., Zacharidis, G., SRATIS, I., 2001: Trace metal concentrations in marine macro algae from different biotopes in the Aegean Sea. Environment International 27, 43-47.

Sergiev, I., Alexieva, V., Karanov, E., 1997: Effect of spermine, atrazine and combination between them on some endogenous protective systems and stress markers in plants, Proceedings of the Bulgarian Academy of Sciences 51, 121-124.

SINGBAL, S. Y. S., 1976: Diurnal variation of some physico-chemical factors in the Mandovi estuary of Goa; Mahasagar Bulletin of the National Institute of Oceanography 9, 27-34. 
Smeets, K., Cuypers, A., Lambrechts, A., Semane, B., Hoet, P., Laere, A. V., VangronsVELD, J., 2005: Induction of oxidative stress and antioxidative mechanisms in Phaseolus vulgaris after Cd application. Plant Physiology and Biochemistry 43, 437-444.

Thom, R., Dixon, D. P., EdwARds, R., Cole, D, L., LAPTHORn, A. J., 2001: The structure of a zeta class glutathione $S$-transferase from Arabidopsis thaliana: characterisation of a GST with novel active-site tyrosine catabolism. Journal of Molecular Biology 308, 949-962.

VAN Assche, F., CliJsters, H., 1990: Effects of metals on enzyme activity in plants. Plant, Cell and Environment 13, 195-206.

WILLS, E. D., 1969: Lipid peroxide formation in microsomes, General considerations. Biochemical Journal 113, 315-324.

Wood, J. M., 1974: Biological cycles for toxic elements in the environment. Science 183, 1049-1052.

ZAR, J. H., 1996: Biostatistical analysis. Prentice Hall, Upper Saddle River. 